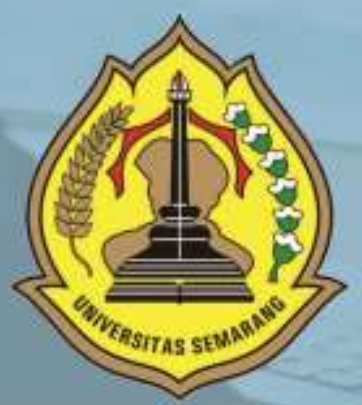

P-ISSN: 1412-5331, E-ISSN: 2716-2532 MAJALAH ILMIAH FAKULTAS EKONOMI UNIVERSITAS SEMARANG

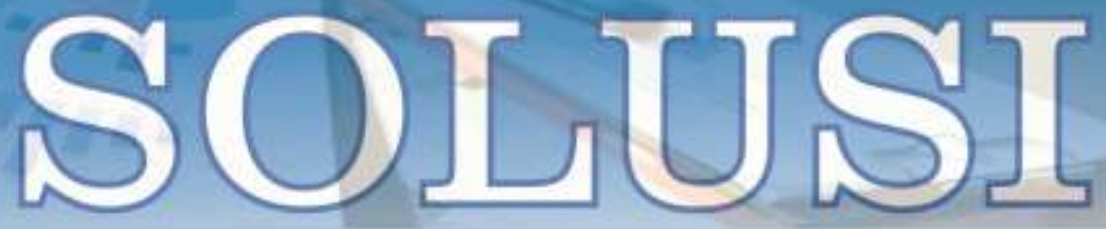

PENGARUH TINGKAT LITERASI KEUANGAN, SIKAP INDIVIDU TERHADAP MINAT INVESTASI SAHAM DI KALANGAN MAHASISWA S2 MAGISTER MANAJEMEN UNIVERSITAS SEMARANG (Asah Wiari Sidiq: Asih Niati - Universitas Semarang)

PENINGKATAN KINERJA PENGAJARAN DOSEN MELALUI KEPEMIMPINAN TRANSFORMASIONAL DAN PEMENUHAN KEBUTUHAN PSIKOLOGIS DASAR DENGAN PEMEDIASI MOTIVASI KER.JA (Anik Herminingsih - Universitas Mercu Buana)

PENGARUH PAJAK, TUNNELING INCENTIVE DAN GOOD CORPORATE GOVERNANCE (GCG) DAN MEKANISME BONUS TERHADAP INDIKASI TRANSFER PRICING PADA PERUSAHAAN MANUFAKTUR (Arum Sasi Andayani; Andiani Ika Sulistyanuati - Liniversitas Semarang)

PENGELOLAAN ALOKASI DANA DESA: AKUNTABILITAS DAN TRANSPARANSI (STUDI KASUS PADA DESA GINGGANGTANI, KECAMATAN GUBUG, KABUPATEN GROBOGAN) (Ana Rokhatt: Saifidin: Dian Trivani - Universitas Semarang)

PENERAPAN STRATEGI BAURAN PEMASARAN PADA USAHA KECIL TELUR ASIN DI KELURAHAN TEGAL SARI, KECAMATAN CANDI SARI, SEMARANG (Nisa Novia Avien Christy; Dwi Widi Pratito - Universitas Semarang)

FAKTOR-FAKTOR YANG MEMPENGARUHI PROFITABILITAS LEMBAGA PERKREDITAN DESA (LPD) DI KABUPATEN BADUNG (Ida Ayu Nyoman Yuliastuti, Putu Kepramareni, I Gusti Ayu Asta Yunisari - Universitas Mahasaraswati Denpasar)

KEBERHASILAN MEMPERTAHANKAN WARUNG MAKAN PRASMANAN MBAH SAN (Sri Wulandari: Susanto - Universitas Semarang)

BRAND PERSONALITY DAN GENDER BRAND PERSONALITY STRATEGI MEMBANGUN MEREK (Haris Murwanto - Universitas Semarang)

POLA PERMINTAN DAN PENAWARAN KETERSEDIAAN DAGING SAPI NASIONAL TAHUN 2030 DENGAN PENDEKATAN FORECASTING (Moeljono - Universitas Semarang)

PENGARUH BRAND IMAGE, KUALITAS PRODUK, PERSEPSI HARGA TERHADAP KEPUTUSAN PEMBELIAN (STUDI KASUS PADA PRODUK SUSU NATURSOYA CV. GLOBAL MANDIRI SEJAHTERA KANCA PURWODADI)

(Ajeng Ayr Fatimah P: Soedarmadi - Untversitas Semarang) 


\section{DESKRIPSI}

Majalah IImiah Solusi Mengkaji

Masalah-Masalah Sosial,

Ekonomi dan Bisnis

\section{KETERANGAN TERBIT}

Terbit Pertama Kali Juli 2002

dan SelanjutnyaTerbit Tiga Bulan

Sekali (Januari, April, Juli dan

Oktober)

\section{PENERBIT}

Fakultas Ekonomi USM

\section{ALAMAT PENERBIT}

JL. Soekarno Hatta Semarang

Telp. 024-6702757 Fax. 024-6702272

\section{PENGELOLA}

Editor in Chief : Yohanes Suhardjo, SE, M.Si., Ak, CA Vice Editor Chief : Sugeng Rianto, SE, MM

Managing Editor: Edy Suryawardana, SE, MM

Secretary of Managing Editor : Asih Niati, SE, MM

Administration \& Circulation :

Citra Rizkiana, SE, MM

Layout \& Typesetting : M Burhan Hanif S.Kom, M.Kom

Board of Editors:

1. Prof. Dr. Ir. Kesi Widjajanti, SE, MM (USM)

2. Prof. Drs. Mohammad Nasir, Msi, Ph.D, AK. (USM)

3. Prof. Supramono SE, MBA, DBA (UKSW)

4. Prof. Drs. H. Imam Ghozali, M.Com, Akt, PhD (UNDIP)

5. Prof. Dr. Agus Suroso, MS (UNSOED)

6. Prof. Dr. Widodo, SE, M.Si (UNISSULA)

7. Prof. Dr. Dra. Sulastri, ME, M.Kom (UNSRI)

8. Dr. Ardiani Ika S, SE, MM, Ak, CA, CPA (USM)

\section{KATA PENGANTAR}

Sungguh merupakan kebahagiaan tersendiri bagi kami, takala kami dapat hadir rutin setiap tiga bulan sekali untuk saling bertukar pikiran mengenai hal-hal baru dibidang sosial, ekonomi dan bisnis.

Pada kesempatan ini penerbit menyampaikan terima kasih kepada semua pihak yang telah mengirimkan artikel-artikelnya. Penerbit akan membuka kesempatan seluas-luasnya bagi seluruh kalangan akademisi maupun praktisi baik dari dalam maupun luar Universitas Semarang untuk mempublikasikan karya ilmiahnya.

Penerbitan majalah ilmiah "SOLUSI" kali ini menghadirkan 10 (Sepuluh) artikel yang kami anggap layak untuk diterbitkan, dengan harapan dapat menjadi tambahan referensi bagi para pembaca dan menjadi sumbangan pengembangan persemaian khasanah pengetahuan dibidang sosial, ekonomi dan bisnis.

Akhir kata semoga majalah ilmiah "SOLUSI" dapat memberi manfaat yang sebesar-besarnya.

Hormat Kami 


\section{DAFTAR ISI}

PENGARUH TINGKAT LITERASI KEUANGAN, SIKAP INDIVIDU

TERHADAP MINAT INVESTASI SAHAM DI KALANGAN MAHASISWA S2 MAGISTER MANAJEMEN UNIVERSITAS SEMARANG

(Asah Wiari Sidiq; Asih Niati - Universitas Semarang).......

PENINGKATAN KINERJA PENGAJARAN DOSEN MELALUI

KEPEMIMPINAN TRANSFORMASIONAL DAN PEMENUHAN KEBUTUHAN PSIKOLOGIS DASAR DENGAN PEMEDIASI MOTIVASI KERJA

(Anik Herminingsih - Universitas Mercu Buana)

PENGARUH PAJAK, TUNNELING INCENTIVE DAN GOOD CORPORATE GOVERNANCE (GCG) DAN MEKANISME BONUS TERHADAP INDIKASI TRANSFER PRICING PADA PERUSAHAAN MANUFAKTUR

(Arum Sasi Andayani; Ardiani Ika Sulistyawati - Universitas Semarang)

PENGELOLAAN ALOKASI DANA DESA: AKUNTABILITAS DAN TRANSPARANSI

(STUDI KASUS PADA DESA GINGGANGTANI, KECAMATAN GUBUG, KABUPATEN GROBOGAN)

(Ana Rokhati; Saifudin; Dian Triyani - Universitas Semarang).

PENERAPAN STRATEGI BAURAN PEMASARAN PADA USAHA KECIL TELUR ASIN DI KELURAHAN TEGAL SARI, KECAMATAN CANDI SARI, SEMARANG

(Nisa Novia Avien Christy; Dwi Widi Pratito - Universitas Semarang)

FAKTOR-FAKTOR YANG MEMPENGARUHI PROFITABILITAS LEMBAGA PERKREDITAN DESA (LPD) DI KABUPATEN BADUNG

(Ida Ayu Nyoman Yuliastuti; Putu Kepramareni; I Gusti Ayu Asta Yunisari - Universitas Mahasaraswati Denpasar)..... .75

KEBERHASILAN MEMPERTAHANKAN WARUNG MAKAN PRASMANAN MBAH SAN

(Sri Wulandari; Susanto - Universitas Semarang).....

BRAND PERSONALITY DAN GENDER BRAND PERSONALITY STRATEGI MEMBANGUN MEREK

(Haris Murwanto - Universitas Semarang).

POLA PERMINTAN DAN PENAWARAN KETERSEDIAAN DAGING SAPI NASIONAL TAHUN 2030 DENGAN PENDEKATAN FORECASTING

(Moeljono - Universitas Semarang)......

PENGARUH BRAND IMAGE, KUALITAS PRODUK, PERSEPSI HARGA TERHADAP KEPUTUSAN PEMBELIAN (STUDI KASUS PADA PRODUK SUSU NATURSOYA CV. GLOBAL MANDIRI SEJAHTERA KANCA PURWODADI)

(Ajeng Ayu Fatimah P; Soedarmadi - Universitas Semarang) 


\title{
PENGARUH BRAND IMAGE, KUALITAS PRODUK, PERSEPSI HARGA TERHADAP KEPUTUSAN PEMBELIAN (Studi Kasus pada Produk Susu NaturSoya CV. Global Mandiri Sejahtera KanCa Purwodadi)
}

\author{
Ajeng Ayu Fatimah P. \\ Soedarmadi
}

\section{Fakultas Ekonomi Universitas Semarang}

Diterima: November 2019, Disetujui:Desember 2019,Dipublikasikan: Januari 2020

\begin{abstract}
This study aims to examine, analyze, and explain the influence of brand image, product quality and price perception on purchasing decisions simultaneously and partially, and to know which independent variable (brand image, product quality and price perception) which has the dominant influence on the dependent variable (buying decision).

The research method used in this study is a quantitative research method using a sample of 40 respondents. Sampling using purposive sampling technique. The data analysis method used in this study is descriptive analysis method and multiple linear regression analysis. Data processing is done using SPSS 25 computer software for Windows.

The results showedthat thequality of the brand image $(X 1)$, product quality $(X 2)$, price perception $(X 3)$ positive and significant impacton purchasing decisions. Based on the significance testt, variableBrand image has the greatest significance influenceon purchasing decisions Keywords: Brand Image, Product Quality, Price Perception, Purchase Decision
\end{abstract}

\begin{abstract}
ABSTRAK
Penelitian ini bertujuan untuk mengkaji, menganalisa, dan menjelaskan pengaruh brand image, kualitas produk dan persepsi harga terhadap keputusan pembelian secara simultan dan parsial, serta mengetahui variabel independen (brand image, kualitas produk dan persepsi harga) manakah yang memiliki pengaruh yang dominan terhadap variabel dependen (keputusan pembelian).

Metode penelitian yang digunakan dalam penelitian ini adalah metode penelitian kuantitatif dengan menggunakan sampel sebanyak 40 responden. Pengambilan sampel menggunakan teknik purposive sampling. Metode analisis data yang digunakan dalam penelitian ini adalah metode analisis deskriptif dan analisis regresi linier berganda. Pengolahan data dilakukan dengan menggunakan software komputer SPSS 25 for Windows.

Hasil penelitian menunjukkan bahwa Brand Image(X1), Kualitas Produk(X2), Persepsi Harga(X3) berpengaruh positif dan signifikan terhadap keputusan pembelian. berdasarkan uji signifikansi t, variabel Brand image mempunyai pengaruh yang signifikan paling besar terhadap keputusan pembelian. Kata kunci: brand image, Kualitas Produk, Persepsi Harga, Keputusan Pembelian
\end{abstract}

\section{PENDAHULUAN}

\section{Latar Belakang Masalah}

Strategi Pemasaran sangat penting diterapkan pada semua bidang yang berkaitan dengan bisnis. Hal ini dikarenakan ketatnya persaingan di bidang bisnis menuntut semua pelaku bisnis berpikir secara kreatif dan inovatif untuk menarik perhatian banyak konsumen. Pelaku bisnis pada saat ini telah banyak menciptakan upaya-upaya pengembangan strategi pemasaran dengan memanfaatkan peluang - peluang dengan 
cara mengikuti permintaan pasar dan perkembangan jaman, hal ini bertujuan untuk menarik perhatian konsumen agar dapat mencapai target penjualan yang diharapkan. Persaingan yang semakin ketat di dalam usaha jasa, dimana semakin banyak produsen yang terlibat dalam pemenuhan kebutuhan dan keinginan konsumen menyebabkan setiap perusahaan harus menempatkan orientasi pada kebutuhan konsumen sebagai tujuan utama (Tjiptono, 1997).

Pada zaman sekarang ini, persaingan yang sangat tajam pada dunia bisnis baik dalam pasar domestik maupun internasional untuk memenangkan persaingan perusahaan harus mampu memberikan kesan yang baik kepada para konsumennya yang berkaitan dengan produk, misalnya: hubungan antara harga dan produk, kualitas produk, manfaat produk, desain produk, brand image dan jenis produk yang di tawarkan kepada konsumen.

Pada era masa kini, memberikan pengaruh yang cukup besar bagi pemasaran dan menumbuhkan tantangan-tantangan baru dalam profesi pemasaran saat ini. Pemasar dituntut untuk dapat memahami bagaimana kejadian-kejadian yang ada di berbagai wilayah yang mempengaruhi pasar domestik dan peluang pencarian terobosan baru, dan tentu saja perkembangan-perkembangan tersebut akan mempengaruhi pola pemasaran perusahaan dengan beragamnya permintaan konsumen membuat para pengusaha berlomba-lomba untuk mendapatkan simpati dari calon pelanggannya. Bila konsumen telah memutuskan untuk menjadi pelanggan maka akan kembali membeli produk yang di produksi dari perusahaan tersebut. Pengaruh yang besar dari Brand Image yang dibentuk oleh pemasar dapat membetuk persepsi konsumen dalam memutuskan pembelian produk. Pemasar harus berusaha keras untuk menarik antusiasme konsumen agar brand image yang dibentuk tercapai. Beberapa temuan dalam menarik antusiasme konsumen (Philip Kotler dan Kevin Lane Keller, 2008) yaitu orang cenderung lebih memperhatikan rangsangan yang berhubungan dengan kebutuhannya saat ini. Artinya adalah orang yang termotivasi untuk membeli Susu NaturSoya akan memperhatikan Image Product yang sudah ada di pasaran, ia tidak akan terlalu memperhatikan produk susu lainnya. (Asosiasi Pemasaran dalam Kotler dan Kevin Lane 2008:332) mendefinisikan Merek (Brand) sebagai nama, istilah, tanda, simbol, atau rancangan atau kombinasi dari semuanya, yang dimaksudkan untuk 
mengidentifikasi barang dan jasa penjual atau kelompok dan untuk mengidentifikasikannya dari barang atau jasa pesaing.

Kualitas produk merupakan hal penting yang harus di usahakan oleh setiap pemasar jika ingin yang dihasilkan dapat bersaing di pasar untuk memuaskan kebutuhan dan keinginan konsumen. Kualitas merupakan syarat utama agar produk yang di pasarkan dapat di terima. Suatu produk dapat dikatakan berkualitas apabila produk tersebut mampu memenuhi harapan pelanggan. Berbagai usaha ditempuh pemasar untuk menghasilkan produk yang berkualitas, antara lain dengan menerapkan kontrol yang ketat pada setiap proses mulai dari penyiapan bahan baku sampai penyimpanan produk jadi. Saat ini, konsumen semakin selektif dan kritis dalam mengkonsumsi suatu produk. Aspek yang perlu di perhatikan dalam produk adalah kualitas produk. Kulaitas Produk merupakan pemahaman bahwa produk yang di tawarakn oleh penjual mempunyai nilai jual yang tidak di miliki oleh produk pesaing (Nela, 2012). Sehingga definisi inidapat di katakan bahwa pemasar telah memenuhi harapan konsumen.

Konsumen selalu ingin mendapatkan produk yang berkualitas sesuai dengan harga yang dibayarkan, meskipun ada sebagian konsumen yang beranggapan bahwa produk mahal adalah produk yang berkualitas. Kualitas produk yang baik dan harga yang terjangkau merupakan pertimbangan sendiri bagi konsumen yang akan membeli sebuah produk.

Kedua hal tersebut, mengenai brand image dan kualitas produk, harga juga merupakan komponen penting dari suatu produk, karena akan berpengaruh terhadap keuntungan pemasar. Harga sangat menentukan keberhasilan pemasar dalam penjualan produk, mengingat pada zaman sekarang ini diketahui bahwa komsumen lebih menggemar produk atau jasa yang lebih murah (low cost) dan juga dengan kualitas yang baik. Apabila harga yang di tetapkan terlalu tinggi akan menyebabkan penjualan akan menurun, namun jika harga terlalu rendah akan mengurangu keuntungan yang dapat di peroleh pemasar, di sisi lain konsumen juga akan menganggap produk yang murah itu tidak berkualitas. Selain itu, bagi konsumen harga merupakan faktor yang menentukan dalam pengambilan keputusan, hal ini dikarenakan konsumen memutuskan membeli suatu produk apabila manfaat yang dirasakan lebih basar atau sudah mencakup apa yang diharapkan. 
Sehubungan dengan kebutuhan manusia yang paling mendasar adalah kebutuhan akan pangan yang mana setiap manusia akan berusaha memenuhi kebutuhan tersebut dengan berbagai cara. Berdasarkan tingkat konsumsi makanan dan minuman yang cukup tinggi, sekor industri makanan dan minuman berkembang dengan pesat memberikan nilai tambah (value adde) yang berbeda terhadap produk dan jasa layanan yang diberikan pada konsumen.

Salah satu usaha kebutuhan pangan yang terkenal di Purwodadi yaitu Gomars dengan produk andalan Natur Soya produksi CV. Global Mandiri Sejahtera Kacab Purwodadi ini sangat diminati oleh masyarakat. Tidak hanya sekedar minuman biasa, inovasi produk ini bermacam macam dari varian rasa dan tipe produk yang dapat dikonsumsi langsung atau dapat diaplikasikan dengan tubuh. Harga yang di patok mulai dari Rp.25.000 perkotak.

Sekian banyak pilihan produk minuman yang beredar di pasaran, namun banyak hal yang jadi pertimbangan konsumen sampai memilih CV. Global Mandiri Sejahtera Kacab Purwodadi sebagai produsen yang akan memenuhi kebutuhan mereka. Pemasar berusaha untuk selalu memenuhi kebutuhan sesuai dengan kriteria yang diinginkan oleh konsumen, baik itu kualitas produknya, brand image, serta harga sehingga dapat memberikan kepuasan bagi konsumen. Jika hal-hal tersebut tidak di perhatikan, maka kesenjangan dan keinginan atau harapan konsumen terhadap kualitas produk, brand image, harga pada produk susu NaturSoya, oleh karena itu tingkat keberhasilan itu akan tercapai apabila pemasar berkomunikasi dengan baik kepada para pelaggannya. Tergantung pada kualitas produk, pelayanan yang ramah, harga yang terjangkau dan brand image yang terkemas menarik.

Pada tahun 2017 muncul pesaing baru dengan produk yang di pasarkan adalah produk berbahan tumbuh-tumbuhan, dengan ini konsumen akan mudah membandingkan ataupun mengevaluasi produk dengan leluasa.

Ketatnya persaingan di bidang pemasaran mengharuskan pemasar untuk memperhatikan brand image, kualitas produk dan harga yang di bentuk agar menciptakan keptusan pembelian yang tinggi. Keluhan-keluhan konsumen yang diadukan kepada prodsen akan berpengaruh pada tingkat penjualan perusahaan. Seperti yang terjadi bahwa banyak aduan yang muncul bahwa kemasan produk yang mudah peot dan kemasan penutup susu yang tidak praktis sehingga mudah terkontamnasi 
dengan udara. Persepsi harga yang terbentuk oleh sebagian konsumen masih terbilang "cukup mahal".

Berdasarkan data yang didapat menunjukkan bahwa penjualan yang terjadi pada tahun 2013-2016 mengalami kenaikan yang signifikan, namun pada tahun 2017 penurunan yang di alami mencapai 5.488 kotak, sehingga pada tahun 2017 hanya berhasil menjual 10.573 kotak. Meskipun prosedur produksi dan pemasaran yang dilakukan sudah dapat dikatakan baik, namun pada kenyataannya volume penjualan mengalami fluktuasi hingga mengalami penurunan di tahun 2017 dan penurunan yang sangat drastis di tahun 2018.

Menurut penelitian (Prasetya, Yulianto, \& Sunarti, 2018) menyatakan bahwa brand image berpengaruh signifikan terhadap keputusan pembelian. Pengaruh hanya menunjukkan bahwa terdapat pengaruh positif dan signifikan terhadap keputusan pembelian, namun demikian penelitian (Deisy, Lapian, \& Mandaige , 2018) menemukan bahwa brand image yang di tawarkan tidak mempengaruhi konsumen dalam melakukan keputusan pembelian, sehingga brand image tidak berpengaruh signifikan terhadap keputusam pmbelian.

Menurut penelitian (Supriyadi, Fristin, \& K.N, 2016) menyatakan bahwa kualitas produk tidak berpengaruh terhadap variabel keputusan pembelian. Namun pada penelitian (Rahayu, 2017) menyatakan bahwa kualitas produk berpengaruh terhadap keputusan pembelian. Penelitian (Halomon, Samosir, \& Prayoga K, 2015) persepsi harga berpengaruh postif terhadap keputusan pembelian. Namun pada penelitian Wanki, Grace Marlin; Mananeke, Lisbeth; Tawas, Hendra;, 2015) menyatakan bahwa persepsi harga tidak berpengaruh positif dan signifikan terhadap keputusan pembelian. Penelitian (Rachmayanti \& Ady, 2018) menyatakan bahwa kualitas produk berpengaruh signifkan dan berpengaruh secara parsial terhadap keputusan pembelian. Pada penelitian (Nani, 2005) menyatakan bahwa kualitas produk dan harga berpengaruh secara positif dan simultan terhadap keputusan pembelian.

Berdasarkan uraian terdapat ketidak konsistenan hasil penelitian terdahulu (research gap) terkait dengan pengaruh brand image, kualitas produk, dan harga terhadap keputusa pembelian. Maka judul yang di ambil adalah "Pengaruh Brand Image, Kualitas Produk dan Harga Terhadap Keputusan Pembelian pada Produk CV. Global Mandiri Sejahtera KanCa Purwodadi” . 


\section{Rumusan Masalah}

"Bagaimana cara mempertahankan brand image, kualitas produk dan harga tetap menjadi dasar keputusan pembelian produk CV. Global Mandiri Sejahtera.

Dari masalah penelitian tersebut, maka dapat dirumuskan pertanyaan penelitian sebagai berikut : Bagaimana pengaruh brand image terhadap keputusan pembelian produk oleh konsumen? Bagaimana pengaruhkualitas produk terhadap keputusan pembelian produk oleh konsumen? Bagaimana pengaruh harga terhadap keputusan pembelian produk oleh konsumen?

Penelitian ini bertujuan menguji dan mendapatkan bukti empiris, bahwa: Brand Image memengaruhi kepercayaan konsumen, kualitas Produk memengaruhi kepercayaan konsumen serta harga memengaruhi kepercayaan konsumen.

\section{TINJAUAN PUSTAKA}

\section{Pemasaran}

Menurut Kotler (2003:9) "Pemasaran adalah suatu proses sosial dimanaindividu atau kelompok memperoleh apa yang mereka inginkan dan butuhkandengan menciptakan, menawar, dan mempertukarkan produk yang bernilaidengan pihak lain”. Menurut Umar (2005:31) "Pemasaran meliputi keseluruhan sistem yang berhubungan dengan kegiatankegiatan usaha yang bertujuan merencanakan, menentukan harga, hingga mempromosikan dan mendistribusikan barang-barang atau jasa yang akan memuaskan kebutuhan membeli, baik yang aktual maupun potensial".

\section{Bauran Pemasaran}

Menurut Kotler (2004:18) "Bauran pemasaran adalah perangkat alat yang digunakan oleh pemasar untuk mendapatkan tanggapan yang diinginkan dari pasar sasaran”. Menurut Kotler (2003:17) ada 4 unsur bauran pemasaran yaitu: Product (produk), Price (harga), Promotion (promosi) serta Place (tempat). 


\section{Keputusan Pembelian}

Keputusan pembelian adalah suatu tahap dimana konsumen telah memiliki pilihan dan siap untuk melakukan pembelian atau pertukaran antara uang dan janji untuk membayar dengan hak kepemilikan atau penggunaan suatu barang atau jasa (Kotler, 2016). Proses pembelian yang spesifik terdiri dari urutan kejadian berikut : pengenalan masalah kebutuhan, pencarian informasi, evaluasi alternatif, keputusan pembelian dan perilaku setelah pembelian, sehingga jelas bahwa pemasar perlu fokus pada seluruh proses pengambilan keputusan (Sunarto, 2013).

\section{Proses Keputusan Pembelian}

Setiap konsumen dalam menentukan pembelian produk selalu pada akhirnya mengambil sebuah keputusan akhir yaitu produk mana yang akan dipilih untuk di beli. Keputusan pembelian yang di lakukan oleh konsumen tersebut menggambarkan seberapa jauh keberhasilan para pemasar dalam mengkomunikasikan produk yang mereka tawarkan kepada konsumen. Proses ini merupakan akumulasi dari pengaruhpengaruh yang ada, termasuk di dalamnya peranan yang terwujud dalam tahapantahapan tetentu. (Kotler dan Amstrong, 2014)membagi proses keputusan pembelian menjadi lima tahapan berurutan sebagai berikut : Pengenalan Kebutuhan, Pencarian Informasi, Evaluasi Alternatif, Keputusan Pembelian serta Perilaku Pasca Pembelian.

\section{Peran dalam Pembelian}

Perusahaan perlu mengidentifikasikan peran ini karena mereka mempunyai implikasi untuk mendesain produk, menentukan pesan-pesan, dan mengalokasikan anggaran promosi. Mengetahui partisipan utama dan peranannya, akan membantu pemasar menentukan program pemasarannya. Ada lima peran yang dimainkan orang dalam suatu keputusan pembelian, menurut (Anaroga, 2009) yaitu : Pegambil Inisiatif, Yang Mempengaruhi, Pengambil Keputusan, Pembeli serta Pemakai.

\section{Brand Image}

Identitas adalah berbagai cara yang diarahkan perusahaan untuk mengidentifikasikan dirinya atau memposisikan produknya. Sedangkan citra / image, yaitu : "Citra adalah persepsi masyarakat terhadap perusahaan atau produknya". Maka 
jelas bila Citra merek atau "Brand Image" adalah bagaimana suatu merek dapat mempengaruhi persepsi konsumen terhadap perusahaan dan produknya (Kotler, 2016). Suatu yang berkaitan dengan pemikiran atau persepsi konsumen tehadap merek dari sebuah produk. Pemikiran konsumen seperti ini tercipta karena memori yang kuat setelah menerima kegunaan atau manfaat dari produk. Citra merek yang kuat serta didorong oleh produk yang berkuaitas baik nanti yang akan menguasai pasar. Brand image adalah sekumpulan asosiasi merek yang terbentuk dan melekat dibenak konsumen (Rangkuti, 2016).

\section{Kualitas Produk}

Menurut(Ariyoto, 2001) kualitas adalah totalitas bentuk dan karakteristik barang yang menunjukkan kemampuannya untuk memuaskan kebutuhan dan keinginan dari konsumen. Kualitas produk merupakan suatu hal yang penting dalam menentukan pemilihan suatu produk oleh konsumen.

\section{Konsep Kualitas Produk}

Konsep kualitas produk telah menjadi faktor yang sangat dominan terhadap keberhasilan organisasi, baik organisasi profit maupun non profit, karena apabila konsumen merasa bahwa kualitas produk yang diterimanya baik atau sesuai harapan, maka akan merasa puas, percaya dan mempunyai komitmen menjadi konsumen yang loyal (Ukudi dan Setiawan, 2007). "Kualitas memberikan suatu dorongan kepada Konsumen untuk menjalin ikatan yang kuat dengan perusahaan” (Tjiptono, 2008).

\section{Pentingnya Kualitas Produk}

Kualitas produk memiliki peran penting terhadap keputusan pembelian yang dilakukan konsumen, sebab kualitas produk yang baik membawa dampak yang baik untuk perusahaan. (Rusel, 2003) mengidentifikasi peran pentingnya kualitas,

\section{Persepsi Harga}

Dharmmesta dan Handoko (2011:241) mengemukakan harga adalah jumlah uang (ditambah beberapa produk kalau mungkin) yang dibutuhkan untuk mendapatkan sejumlah kombinasi dari produk dan pelayanan. Dinawan (2010:36) mengatakan 
presepsi harga terlihat dari: 1)Perbandingan harga dengan produk lain, yaitu bagaimana perbandingan harga produk dengan produk pesaingnya. 2) Kesesuaian harga dengan kualitas produk, yaitu apakah harga yang ditawarkan sudah sesuai dengan kualitas produk yang didapatkan. 3) Keterjangkauan harga, yaitu adalah keterjangkauan harga yang ditawarkan produsen ke konsumen. Berdasarkan teori tersebut disimpulakan persepsi harga untuk tiap individu adalah relatif dengan demikian adanya penentuan harga yang sesuai dengan produk dapat menjadi acuan yang tepat bagi para konsumen dan pihak pemasaran dalam keputusan pembelian.

\section{Kebijakan Penetapan Harga}

Penetapan harga merupakan suatu masalah ketika perusahaan harus menentukan harga untuk pertama kali. Perusahaan haruslah mempertimbangkan banyak faktor dalam menyusuk kebijakan menetapkan harganya (Thamrin dan Francis, 2014).

\section{Tujun Penetapan Harga}

Penjual barang dalam menetapkan harga dapat mempunyai tujuan yang berbeda satu sama lain. Tujuan penetapan harga menurut (Harini, 2008) adalah sebagai berikut: Penetapan harga untuk mencapai penghasilan, Penetapan harga untuk kestabilkan harga, Penetapan harga untuk mempertahankan atau meningkatkan bagiannya dalam pasar, Penetapan harga untuk menghadapi atau mencegah persaingan serta Penetapan harga untuk memaksimalkan laba.

\section{Hipotesis}

H1 = Terdapat pengaruh positif brand image pada Keputusan Pembelian produk $\mathrm{H} 2$ = Terdapat pengaruh positif kualitas produk pada keputusan pembelian produk. $\mathrm{H} 3$ = Terdapat pengaruh positif harga pada keputusan pembelian produk

\section{Populasi dan Penentuan Sampel}

Populasi dalam penelitian ini adalah karyawan perusahaan CV. Global Mandiri Sejahtera di kota Purwodadi. Sampel adalah bagian dari populasi .yang harus memiliki karakteristik dan sesuai dengan tujuan penelitian (Sugiyono, 2014).Teknik yang digunakan dalam pengambilan sampel penelitian ini adalah menggunakan non 
probability sampling dengan teknik purposive sampling, yaitu pengambilan sampel berdasarkan kriteria-kriteria tertentu antara lain :

1. Karyawan yang telah bekerja minimal 1 tahun.

2. Karyawan yang aktif di perusahaan.

3. Bersedia mengisi kuisoner

Pada penelitian ini, populasi yang digunakan jumlahnya diketahui secara pasti dan terlalu besar ukurannya, maka menurut (Ferdinand, 2013) digunakan rumus Slovin (Ferdinand, 2013). Berdasarkan perhitungan, sampel yang di ambil dalam penelitian di peroleh sebesar 40,12 di bulatkan sebesar 40 orang.

\section{Analisis Data Kuantitatif}

Analisis kuantitatif adalah bentuk analisa yang menggunakan angka-angka dan perhitungan dengan metode statistik untuk menguji kebenaran hipotesis penelitian yang telah diajukan sebelumnya. metode analisis ini digunakan pada data yang diperoleh dari hasil jawaban kuisioner dan dilakukan untuk menganalisis data yang berbentuk angkaangka dan perhitungan dengan metode statistic (pengolahan data menggunakan SPSS).

\section{HASIL PENELITIAN DAN PEMBAHASAN}

\section{Analisis Data}

\section{Uji Validitas dan Uji Realibilitas}

Semua indikator yang digunakan untuk mengukur indikator variabel yang digunakan dalam penelitian ini mempunyai koefisien korelasi dengan signifikan lebih besar dari $r$ tabel sebesar 0,201 dengan demikian semua indikator hasilnya adalah valid.

Hasil Uji Realibilitas menunjukkan semua variabel mempunyai koefisien alpha yang cukup besar yaitu lebih dari 0,70 sehingga dapat dikatakan semua konsep pengukur masingmasing variabel dari kuesioner adalah reliabel.

\section{Uji Normalitas}

Hasil Uji Kolmogorov-Smirnov sebesar 0,99 memiliki signifikan yang lebih besar dari 0,05 yaitu sebesar 0,79 Hal ini berarti bahwa model regresi tersebut sudah berdistribusi normal. 


\section{Pengujian Multikolonieritas dan Pengujian Heteroskedastisitas}

Nilai VIF dari semua variabel bebas memiliki nilai kurang dari 10 . Hal ini berarti bahwa variabel-variabel penelitian tidak menunjukkan adanya gejala multikolonieritas dalam model regresi. Uji Heteroskedastisitas memperlihatkan bahwa pada kolom sig variabel brand image, kualitas produk, harga memiliki nilai sig lebih dari 0,05. Jadi dapat disimpulkan bahwa data tersebut tidak terjadi adanya heteroskedastisitas sehingga layak untuk digunakan dalam pengujian.

\section{Analisis Regresi Linear Berganda}

Keputusan Pembelian $=0,494$ Brand Image + 0,221 Kualitas Produk + 0,235 Persepsi Harga

Interpretasi :

1. Koefisien regresi untuk variabel brand image (X1) sebesar 0,494 bernilai positif, artinya bahwa semakin baik brand image atau citra merek maka semakin tinggi tingkat keputusan pembelian.

2. Koefisien regresi untuk variabel kualitas produk (X2) sebesar 0,221 bernilai positif, artinya bahwa semakin baik kualitas produk yang diterima oleh konsumen maka semakin tinggi tingkat keputusan pembelian.

3. Koefisien regresi untuk variabel persepsi harga (X3) sebesar 0,235 bernilai positif, artinya bahwa semakin tinggi harga dengan di imbangi kualitas produk yang sesuai maka semakin tinggi tingkat keputusan pembelian.

\section{Uji Hipotesis (Uji t)}

Hasil pengujian hipotesis 1 mengenai brand image terhadap keputusan pembelian diperoleh koefisien regresi arah positif dan nilai t hitung sebesar 3,469. Dimana nilai t tabel sebesar 1,688 sehingga t hitung lebih besar dari t tabel yaitu 3,469 $>$ 1,688 dengan nilai signifikansi sebesar 0,01. Nilai signifikansi lebih kecil dari 0,05. Hal ini menunjukkan bahwa hipotesis 1 dalam penelitian ini diterima, yang artinya bahwa secara parsial variabel brand image (X1) mempunyai pengaruh positif dan signifikan terhadap keputusan pembelian.

Hasil pengujian hipotesis 2 mengenai pengaruh promosi terhadap loyalitas nasabah diperoleh koefisien regresi arah positif dan nilai t hitung sebesar 1,690. Dimana 
nilai t tabel sebesar 1,688 sehingga t hitung lebih besar dari t tabel, yaitu 1, $690>1,688$ dengan nilai signifikansi sebesar 0,1. Nilai signifkansi lebih kecil dari 0,05. Hal ini menunjukkan bahwa hipotesis 2 dalam penelitian ini diterima, yang artinya bahwa secaraparsial variabel kualitas produk (X2) mempunyai pengaruh positif dan signifikan terhadap keputusan pembelian.

Hasil pengujian hipotesis 3 mengenai harga terhadap keputusan pembelian diperoleh koefisien regresi arah positif dan nilai t hitung sebesar 1,968. Dimana nilai $\mathrm{t}$ tabel sebesar 1,688 sehingga t hitung lebih besar dari t tabel, yaitu 1,968 $>1,688$ dengan nilai signifikansi sebesar 0,57. Nilai signifikansi lebih kecil dari 0,05. Hal ini menunjukkan bahwa hipotesis 3 dalam penelitian ini diterima, yang artinya bahwa secara parsial variabel harga (X3) mempunyai pengaruh positif dan signifikan terhadap keputusan pembelian.

\section{Hasil Uji Koefisien Determinasi}

Hasil menunjukkan nilai R2 pada model regresi diperoleh sebesar 0,692 yang artinya 69,2 persen variabel keputusan pembelian dapat dijelaskan oleh variabel brand image, kualitas produk, harga sedangkan sisanya sebesar 30,8 persen keputusan pembelian dapat dijelaskan oleh faktor-faktor lainnya.

\section{Pembahasan}

\section{Pengaruh Brand Image Terhadap Keputusan Pembelian}

Hasil penelitian ini menunjukkan bahwa variabel brand image berpengaruh positif dan signifikan terhadap keputusan pembelian. Menurut (Rangkuti, 2016) Brand image adalah sekumpulan asosiasi merek yang terbentuk dan melekat dibenak konsumen. Berdasarkan definisi ini, citra merek yang kuat serta didorong oleh produk yang berkuaitas baik nanti yang akan menguasai pasar dan suatu yang berkaitan dengan pemikiran atau persepsi konsumen tehadap merek dari sebuah produk, pemikiran konsumen seperti ini tercipta karena memori yang kuat setelah menerima kegunaan atau manfaat dari produk. Hal tersebut berarti bahwa semakin baik brand image yang diciptakan oleh CV. Globa Mandiri KanCa Purwodadi maka semakin tinggi keputsan pembelian, karena persepsi yang baik dari produk suatu perusahaan akan dapat 
memberikan tingkat pemilihan keputsan pembelian serta pembelian ulang yang lebih sering.

Hasil penelitian ini mendukung penelitian yang dilakukan oleh (Riyono, Gigih, 2016) yang menyatakan bahwa brand image berpengaruh secara posiitif dan signifikan terhadap keputusan pembelian. Dengan demikian baiknya brand image CV. Global Mandiri Sejahtera KanCa Purwodadi akan meningkatkan tingkat keputusan pembelian.

\section{Pengaruh Kualitas Produk Terhadap Keputusan Pembelian}

Hasil penelitian ini menunjukkan bahwa variabel kualitas produk berpengaruh positif dan signifikan terhadap keputusan pembelian. Hal tersebut berarti bahwa keputusan produk meningkat seiring dengan meningkatnya kualitas produk yang dilakukan oleh CV. Global Mandir Sejahtera KanCa Purwodadi. Hal ini juga diperkuat oleh (Ariyoto, 2001) kualitas adalah totalitas bentuk dan karakteristik barang yang menunjukkan kemampuannya untuk memuaskan kebutuhan dan keinginan dari konsumen. Kualitas produk merupakan suatu hal yang penting dalam menentukan pemilihan suatu produk oleh konsumen. Produk yang ditawarkan haruslah suatu produk yang benar-benar teruji dengan baik mengenai kualitasnya. Karena bagi konsumen yang diutamakan adalah kualitas dari produk itu sendiri. Konsumen akan lebih menyukai dan memilih produk yang mempunyai kualitas lebih baik bila dibandingkan dengan produk lain sejenis yang dapat memenuhi kebutuhan dan keinginannya.

Hasil penelitian ini di dukung oleh penelitian (Suharni, 2017) yang menyatakan bahwa kualitas produk berpengaruh positif dan signifikan terhadap keputusan pembelian. Demikian dengan CV. Global Mandir Sejahtera KanCa Purwodadi, semakin baik kualitas produk yang di ciptakan maka akan semakin tinggi tingkat keputusan pembelian oleh konsumen.

\section{Pengaruh Persepsi Harga Terhadap Keputusan Pembelian}

Hasil penelitian ini menunjukkan bahwa variabel harga berpengaruh positif dan signifikan terhadap keputusan pembelian. Menurut (Tjiptono F. , 2008) menyebutkan bahwa harga merupakan satu-satunya unsur bauran pemasaran yang memberikan pemasukan atau pendapatan bagi perusahaan. Hal tersebut berarti bahwa semakin tinggi 
tingkat harga yang di tetapkan dengan di iringi kualitas produk yang baik maka semakin tinggi tingkat keputusan pembelian oleh konsumen.

Hasil penelitian mendukung penelitian yang dilakukan oleh (Dian, 2017) menyatakan bahwa harga berpengaruh positif dan signifikan terhadap keputusan pembelian.

\section{PENUTUP}

\section{Kesimpulan}

1. Ada pengaruh positif dan signifikan antara brand image (X1) terhadap keputusan pembelian (Y). Semakin baik brand image yang diciptakan oleh CV. Global Mandiri Sejahtera KanCa Purwodadi maka semakin meningkat keputusan pembelian oleh konsumen. Hal ini dapat dilihat $t$ hitung lebih besar dari pada t tabel, maka hipotesis yang menyatakan bahwa brand image mempunyai pengaruh positif dan signifikan terhadap keputusan pembelian dapat diterima.

2. Ada pengaruh positif dan signifikan antara kualitas produk (X2) terhadap keputusan pembelian (Y). Semakin baik dan semakin banyak varian rasa dan jenis olahan produk oleh CV. Global Mandiri Sejahtera KanCa Purwodadi maka akan semakin meningkat keputusan pembelian oleh konsumen. Hal ini dapat dilihat dari t hitung lebih besar dari $\mathrm{t}$ tabel, maka hipotesis yang menyatakan bahwa kualitas produk mempunyai pengaruh positif dan signifikan terhadap keputusan pembelian dapat diteima.

3. Ada pengaruh positif dan signifikan antara persepsi harga (X3) terhadap keputusan pembelian (Y). Semakin tinggi harga yang di iringin dengan kualitas produk yang bagus akan meningkatkan keputusan pembelian oleh konsumen. Hal ini dapat dilihat dari $\mathrm{t}$ hitung lebih besar dari $\mathrm{t}$ tabel, maka hipotesis yang menyatakan bahwa harga mempunyai pengaruh positif dan signifikan terhadap keputusan pembelian dapat diterima.

\section{Saran}

Dari kesimpulan diatas maka saran yang dapat dikemukakan pada penelitian ini adalah : 1. Hasil pengujian deskriptif pada variabel brand image, pada indikator pengakuan mendapatkan skor terendah, disarankan agar CV. Global Mandiri Sejahtera KanCa Purwodadi melakukan inovasi produk atau pada perikalanan secara terus menerus, 
dengan cara meng-upgrade produk menjadi leih baik sehingga mempunyai ciri khas tersendiri bagi konsumen.

2. Hasil pengujian deskriptif pada variabel kualitas produk, pada indikator rasa mendapatkan skor terendah, disarankan agar CV. Global Mandiri Sejahtera KanCa Purwodadi megurangi rasa pait pada beberapa varian produk, dengan cara menambahkan creamy sugar sachet yang dapat di aplikasikan konsumen saat mengkonsumsi, atau dengan cara menambhakan pemanis pada produk.

3. Hasil pengujian pada variabel perseps harga, pada indikator daya saing harga mendapatkan skor terendah, disarankan agar CV. Global Mandiri Sejahtera KanCa Purwodadi membuat harga sedikit lebih murah dari harga pesaing atau menyederhanakan produk dengan paket. Caranya yaitu dengan membuat paket kemasan agar konsumen mempersepsikan bahwa dengan membeli paket kemasan akan lebih efektif dan terjangkau.

4. Hasil pengujian pada variabel keputusan pembelian, pada indikator rekomendasi mendapatkan skor terendah, disarankan agar CV. Global Mandiri Sejahtera KanCa Purwodadi menyarankan pada konsumen untuk mengajak teman untuk melakukan pembelian dengan cara mengadakan promo buy one take two all you need, dan mengadakan event dorprice dimana para konsumen yang datang akan secara tidak sengaja mengajak teman atau saudara yang lain.

\section{Keterbatasan Penelitian}

1. Hanya fokus pada tiga variabel yang diteliti dalam mempengaruhi keputusan pembelian, yaitu brand image, kualitas produk dan harga dengan nilai sebesar 70,1 persen.

2. Penelitian ini hanya mengambil objek penelitian pada CV. Global Mandiri Sejahtera KanCa Purwodadi.

\section{Agenda Penelitian Yang Akan Datang}

1. Perlu dilakukan lebih lanjut terhadap faktor-faktor selain brand image, kualitas produk dan harga yang berpengaruh pada keputsan pembelian misalnya lokasi, promosi, minat beli dan lain-lain. 
2. Diharapkan pada penelitian mendatang sebaiknya mengambil objek penelitian yang berbeda. Penelitian pada objek perusahaan yang berbeda meskipun dengan model penelitian yang sama.

\section{DAFTAR PUSTAKA}

Agustina, E. (2017). Pengaruh Kualitas Produk, Harga, Dan Citra Merek Terhadap Keputusan Pembelian One Push Vape Di Kecamatan Kertosono (Studi Kasus Pada Damai Swalayan Kertosono) . Simki-Economic .

Alma, \& Buchari. (2011). Pemasaran Dan Pemasaran Jasa.

Anaroga, P. (2009). 5 Peran Dalam Keputusan Pembelian. Belajar Manajmen, Learning About Management Of Finance, Marketing, Hr Production, Strategy And Leadership.

Ariyoto. (2001). Pengaruh Kualitas Produk Terhadap Keputusan Pembelian Dan Dampaknya Terhadap Kepuasan Konsumen Pengguna Iphone (Survei Pada Mahasiswa Fakultas Ilmu Administrasi Universitas Brawijaya Malang). Jurnal Administrasi Bisnis (Jab).

Deisy, M., Lapian, J., \& Mandagie, Y. (2018). Analisis Citra Merek, Harga Produk Dan Kualitas Terhadap Keputusan Pembelian Handphone Samsung Pada Seluruh Gerai - Gerai Seluler Di It Center Manado . Jurnal Emba .

Deisy, M., Lapian, J., \& Mandaige , Y. (2018). Analisis Citra Merek, Harga Produk Dan Kualitas Terhadap Keputusan Pembelian Handphone Samsung Pada Seluruh Gerai - Gerai Seluler Di It Center Manado . Jurnal Emba.

Ferdinand, A. T. (2006). Metode Penelitian Manajemen. Semarang: Badan Penerbit Universitas Diponegoro.

Ferrindawati. (2011, Agustus 02). Pengaruh Brand Image Terhadap Keputusan Pembelian Cafe Lawang Wangi Creative Space(Studi Pada Masyarakat Bandung 2016). E-Proceeding Of Applied Science, 02, 501.

Ghozali. (2011). Aplikasi Analisis Multivariate Dengan Program Ibm Spss 19. Edisi Kelima. Semarang: Badan Penerbit Universitas Diponegoro.

Ghozali, I. (2012). Aplikasi Analisis Multivariati Dengan Program Spss. Semarang: Badan Penerbit - Universitas Diponegoro.

Grgory. (2012). Pengaruh Brand Image Terhadap Keputusan Pembelian Cafe Lawang Wangi Creative Space(Studi Pada Masyarakat Bandung 2016). E-Proceeding Of Applied Science.

H.S, C. F., \& Prayoga K, A. B. (2015). Jurnal Pengaruh Persepsi Harga Dan Promosi Terhadap Keputusan Pembelian Konsumen Produk Enervon-C. Jurnal Ilmiah Manajemen Dan Bisnis .

Halomon, C. B., Samosir, \& Prayoga K, A. B. (2015). Jurnal Pengaruh Persepsi Harga Dan Promosi Terhadap Keputusan Pembelian Konsumen Produk Enervon-C . Jurnal Ilmiah Manajemen Dan Bisnis.

Harini. (2008). Pengaruh Kualitas Produk Dan Harga Terhadap Keputusan Pembelian Produk Kosmetik Wardah Di Kota Bangkalan Madura. Jurnal Ekonomi \& Bisnis.

Hasan. (2013). Pengaruh Kualitas Produk, Harga Dan Kualitas Layanan Terhadap Keputusan Pembelian Kartu Indosat Im3 (Studi Pada Pt. Indo Harmoni Makmur Manado). Jurnal Emba. 
Hasan, A. (2013). Pengaruh Kualitas Produk, Harga Dan Kualitas Layanan Terhadap Keputusan Pembelian Kartu Indosat Im3 (Studi Pada Pt. Indo Harmoni Makmur Udi Pada Pt. Indo Harmoni Makmur Manado). Jurnal Emba.

Keller. (2016). Pengaruh Brand Image Terhadap Keputusan Pembelian. Jurnal Administrasi Bisnis (Jab).

Kotler. (2016). Pengaruh Brand Image Terhadap Keputusan Pembelian Smartphone Android Samsung Di Kota Palembang. Jurnal Ilmiah Manajemen Bisnis Dan Terapan.

Kotler. (2016). Pengaruh Ekuitas Merek Dan Gaya Hidup Terhadap Keputusan Pembelian Mobil Nissan Juke. Jurnal Ilmu Dan Riset Manajemen.

Kotler Dan Amstrong. (2014). Pengaruh Atribut Produk Terhadap Keputusa Pembelian Studi Pada Mahasiswa Pembeli Produk Handphone Samsung Fakultas Ilmuadministrasi Jurusan Administrasi Bisnis Angkatan 2009-2012 Unniversitas Brawijaya Malang. Administrasi Bisnis (Jab), 15.

Nani. (2005). Pengaruh Word Of Mouth, Harga Produk Dan Kulaitas Produk Terhadap Keputusan Pembelian Produk Minuman Jahe Merah Instan (Studi Kasus Pada Industri Rumah Tangga Enam Putri Jakarta). Inovasi Jurnal Ilmiah Lmu Manajemen.

Nazir, M. (2014). Metode Penelitian. Bogor: Ghalia Indonesia.

Philip Kotler Dan Kevin Lane Keller. (2008). Manajemen Pemasaran Edisi Tiga Belas Jilid 1. Jakarta: Erlangga.

Prasetya, E. G., Yulianto, E., \& Sunarti. (2018). Pengaruh Brand Image Terhadap Keputusan Pembelian (Survei Pada Mahasiswa Fakultas Ilmu Administrasi Bisnis Progam Studi Administrasi Bisnis Angkatan 2014 Konsumen Air Mineral Aqua ) . Jurnal Administrasi Dan Bisnis (Jab).

Rachmayanti, I., \& Ady, S. U. (2018). Kualitas Produk Sebagai Variabel Pemicu Utama Keputusan Pembelian Susu Formula Sgm Explore Di Kota Surabaya. Ekspektra: Jurnal Bisnis Dan Manajemen.

Rahayu, S. (2017). Pengaruh Kualitas Produk Terhadap Keputusan Pembelian Pada Majalah Media Asuransi (Studi Kasus: Pt. Media Asuransi Indonesia) . Jurnal Pemasaran Kompetitif Manajemen Pemasaran.

Rangkuti. (2016). Pengaruh Brand Image Terhadap Keputusan Pembelian (Studi Pada Pembeli Kartu Perdana Simpati Di Booth Telkomsel Matos). Jurnal Administrasi Bisnis (Jab).

Riyono, Gigih. (2016). Pengaruh Kualitas Produk, Harga, Promosi Dan Brand Image Terhadap Keputusan Pembelian Produk Aqua Di Kota Pati. Jurnal Stie Semarang, Vol 8, No 2.

Rusel. (2003). Pengaruh Kualitas Produk Terhadap Keputusan Pembelian Dan Dampaknya Terhadap Kepuasan Konsumen Pengguna Iphone (Survei Pada Mahasiswa Fakultas Ilmu Administrasi Universitas Brawijaya Malang). Jurnal Administrasi Bisnis (Jab).

Sekaran, U. (2006). Research Methods For Business. Salemba Empat.

Sugiyono. (2007). Metode Penelitian Administrasi. Bandung: Alfabeta.

Sugiyono. (2014). Metode Penelitian Pendidikan Pendekatan Kuantitatif, Kualitatif Dan R\&D. Bandung: Alfabeta.

Suharni. (2017). Pengaruh Kualitas Produk Terhadap Keputusan Pembelian. Jurnal Pemasaran Kompetitif. 
Sunarto. (2013). Ekuitas Merek Pengaruhnya Terhadap Keputusa Pembelian Xl Mobile Data Service Di Kota Manado. Emba.

Supriyadi, Fristin , Y., \& Indra, G. (2016). Pengaruh Kualitas Produk Dan Brand Image Terhadap Keputusan Pembelian. Jurnal Bisnis Dan Manajemen Vol. 3 No.1.

Supriyadi, Fristin, Y., \& K.N, G. I. (2016). Pengaruh Kualitas Produk, Harga, Promosi Dan Brand Image Terhadap Keputusan Pembelian Produk Aqua Di Kota Pati. Jurnal Bisnis Dan Manajemen.

Swastha Dan Irawan. (2002). Pengaruh Harga Dan Kualitas Pelayanan Terhadap Keputusan Penggunaan Jasa Bengkel Pt. Astra International Tbk-Daihatsu Majapahit Semarang. Diponegoro Journal Of Social And Politic Of Science.

Thamrin Dan Francis. (2014). Pengaruh Kualitas Produk Dan Harga Terhadap Keputusan Pembelian Produk Kosmetik Wardah Di Kota Bangkalan Madura. Jurnal Ekonomi \& Bisnis.

Tjiptono. (2008). Pengaruh Kualitas Produk Terhadap Keputusan Pembelian Dan Dampaknya Terhadap Kepuasan Konsumen Pengguna Iphone (Survei Pada Mahasiswa Fakultas Ilmu Administrasi Universitas Brawijaya Malang). Jurnal Administrasi Bisnis (Jab).

Tjiptono, F. (2008). Jurnal Ekonomi \& Bisnis Pengaruh Kualitas Produk Dan Harga Terhadap Keputusan Pembelian Produk Kosmetik Wardah Di Kota Bangkalan Madura.

Ukudi Dan Setiawan. (2007). Pengaruh Kualitas Produk Terhadap Keputusan Pembelian Dan Dampaknya Terhadap Kepuasan Konsumen Pengguna Iphone (Survei Pada Mahasiswa Fakultas Ilmu Administrasi Universitas Brawijaya Malang). Jurnal Administrasi Bisnis (Jab).

Wanki, Grace Marlin; Mananeke, Lisbeth; Tawas, Hendra;. (2015). Pengaruh Bauran Promosi, Persepsi Harga Dan Lokasi Terhadap Keputusan Pembelian Dan Kepuasan Konsumen Pada Perumahan Tamansari Metropolitan Manado . Jurnal Emba.

Wariki, G. M., Mananeke, L., \& Tawas, H. (2015). Pengaruh Bauran Promosi, Persepsi Harga Dan Lokasi Terhadap Keputusan Pembelian Dan Kepuasan Konsumen Pada Perumahan Tamansari Metropolitan Manado . Jurnal Emba .

Zed, M. (2004). Metode Penelitan Kepustakaan. Jakarta: Yayasan Obor Indonesia. 